\title{
PREGLED VEGETACIJSKIH ISTRAŽIVANJA U ŠUMAMA HRASTA CRNIKE (Quercus ilex L.) NA POKUSNIM PLOHAMA U HRVATSKOJ
}

\section{OVERVIEW OF VEGETATION RESEARCH IN HOLM OAK FORESTS (Quercus ilex L.) ON EXPERIMENTAL PLOTS IN CROATIA}

Damir BARČIĆ ${ }^{1}$,̌eljko ŠPANJOL ${ }^{2}$, Roman ROSAVEC ${ }^{3}$, Mario ANČIĆ ${ }^{4}$, Tomislav DUBRAVAC ${ }^{5}$, Sanja KONČAR ${ }^{6}$, Ivan LJUBIĆ7 , Ivona RIMAC ${ }^{8}$

\begin{abstract}
SAŽETAK
U vegetacijskom smislu, šume hrasta crnike sastavni su dio mediteranske regije, a hrast crnika se pojavljuje kao edifikator klimatogene zajednice vazdazelenog pojasa. Tijek razvoja vegetacije u smislu progresije i regresije prikazan je sukcesijom crnikovih šuma. Sukcesija je prisutna ne samo na hrvatskoj obali Jadrana, nego i u cijelom Sredozemlju. U radu je prikazan pregled vegetacijskih analiza i dinamika razvoja crnikovih šuma. Istraživanjem su obuhvaćene samo MAB plohe i plohe na otoku Rabu na poluotoku Kalifrontu osnivane istraživanjima Rauša, Španjola i Barčića (plohe Šumarskog fakulteta). Uz navedeno u radu je analizirana zapaljivost i gorivost hrasta crnike s obzirom da su šumski požari najveća ugroza za šumsku vegetaciju i općenito raslinje u mediteranskoj zoni.
\end{abstract}

KLJUČNE RIJEČI: eumediteran, sukcesija, dinamika razvoja, monitoring.

\section{UVOD}

\section{INTRODUCTION}

Istraživanja šuma hrasta crnike u Sredozemlju iznimno su bitna u okolnostima i uvjetima degradacije šumskih ekosustava, antropogenog pritiska i očekivanih intenzivnih klimatskih promjena (Valladeres i dr. 2014, Flexas i dr. 2014). Šume hrasta crnike velikim dijelom su sastavni dio antropogenog krajobraza, što često uvjetuje i probleme s obnovom u tim šumama (Espelta i dr. 1995, Moran-Lopez i dr. 2016). Stoga je praćenje stanja i promjena te dinamike razvoja bilo ključno u osnivanju pokusnih ploha u šumama hrasta crnike. U radu se daje pregled te trendovi na trajnim pokusnim plohama, koji bi trebali ukazati na promjene ili pojave koje dovode do nestabilnosti u šumskom ekosustavu. U ovom istraživanju prikupljeni su postojeći podaci s MAB (projekt: Čovjek i biosfera) ploha i trajnih pokusnih ploha s otoka Raba.

\section{Rasprostranjenost hrasta crnike u Sredozemlju i na Jadranu}

Hrast crnika pojavljuje se kao edifikator klimatogene zajednice vazdazelenog pojasa sredozemne regije. Na istok joj se

\footnotetext{
izv. prof. dr. sc. Damir Barčić, Sveučilište u Zagrebu Šumarski fakultet, Svetošimunska 25, Zagreb, dbarcic@sumfak.hr

2 prof. dr. sc. Željko Španjol, Sveučilište u Zagrebu Šumarski fakultet, Svetošimunska 25, Zagreb, zespanjol.rab@gmail.com

${ }^{3}$ doc. dr. sc. Roman Rosavec, Sveučilište u Zagrebu Šumarski fakultet, Svetošimunska 25, Zagreb, rrosavec@sumfak.hr

${ }^{4}$ doc. dr. sc. Mario Ančić, Sveučilište u Zagrebu Šumarski fakultet, Svetošimunska 25, Zagreb, mancic@sumfak.hr

${ }^{5}$ dr. sc. Tomislav Dubravac, Hrvatski šumarski institut, Cvjetno naselje 41, Jastrebarsko, tomod@sumins.hr

${ }^{6}$ Sanja Končar, mag. ing. silv.

${ }^{7}$ Ivan Ljubić, mag. ing. silv.

${ }^{8}$ Ivona Rimac, mag. ing. silv.
} 
areal pruža do Male Azije. Najviše je rasprostranjena u zapadnom Sredozemlju, na Pirenejskom poluotoku (u Španjolskoj pokriva oko 4 milijuna hektara površine) te Alžiru i Maroku. Na sjever najviše dopire do atlantskog primorja južne Francuske, ponešto u područje do južnog Tirola. Na Pirenejima je rasprostranjena do $1400 \mathrm{~m}$, na Etni do 1300 $\mathrm{m}$, a na Atlasu do $2700 \mathrm{~m}$ nadmorske visine (Q. ilex var. ballota).

Na jadranskoj obali Hrvatske hrast crnika pokriva uski rub jugozapadne i južne Istre, prelazi na najjužniji dio Cresa, Raba i Paga, a odatle se pojavljuje na svim otocima prema jugoistoku od Lošinja do Lokruma i Lastova na jugu, te na kopnu od Zadra do Prevlake. U sjevernoj Dalmaciji šuma s česminom dolazi do granice $200 \mathrm{~m}$, a u južnoj do preko 350 m nadmorske visine. Prema Horvatu (1965) kod Splita na jugozapadnoj strani Kozjaka dolazi na visini od 780 m, dok u Baškoj na otoku Krku dolazi do 300 m.

U vegetacijskom smislu šume hrasta crnike sastavni su dio mediteranske regije i to mediteransko-litoralnog i mediteransko-montanskog vegetacijskog pojasa (Trinajstić, 1986). U toj zoni prema istom autoru najvažniji edifikator je hrast crnika ili česmina (Quercus ilex L.) koja tvori nekoliko značajnih biljnih zajednica. Asocijacije hrasta crnike s mirtom (Myrto-Quercetum ilicis/Horvatić 1963/ Trinajstić 1985) i hrasta crnike s crnim jasenom (Fraxino orni-Quercetum ilicis Horvatić/1956/1958) pripadaju eumediteranskoj zoni, dok asocijacija hrasta crnike i crnoga graba (Ostryo-Quercetum ilicis Trinajstić /1965/1977) pripada hemimediteranskoj zoni. Horizontalno raščlanjenje eumediteranske vegetacije zone prema Trinajstiću (1986) je sljedeće:

- područje čistih šuma crnike

- područje mješovitih šuma crnike i crnoga jasena

- područje mješovitih šuma crnike i duba

Čiste vazdazelene šume hrasta crnike zauzimaju otočni dio eumediteranske zone sve do najjužnijih dijelova otoka Lošinja. Temeljna vrsta je hrast crnika, čija šumska vegetacija čini okosnicu za stvaranje različitih degradacijskih stadija vegetacije, makije, pa gariga i naposlijetku kamenjara (Vukelić, 2012). Upravo taj kserotermni dio eumediterana razmjerno je teško odvojiti od stenomediteranske zone. Najveće površine zauzimaju mješovite šume hrasta crnike i crnoga jasena koje tvore prijelaz prema listopadnoj vegetaciji u horizontalnom smjeru. Mješovite šume crnike i duba obuhvaćaju južni dio eumediteranske zone od poluotoka Pelješca te otoke Lastovo, Mljet i Lokrum. Istraživanja poznavanja sastava i raščlanjenosti šuma hrasta crnike pokazala su jasno izdvajanje asocijacije Fraxino orniQuercetum ilicis Horvatić/1956/1958 od drugih asocijacija u kojima je temeljna vrsta hrast crnika (Baričević i dr. 2013). Nadalje prema Baričevići i Šapić (2011) rezultati analiza asocijacije Fraxino orni-Quercetum ilicis uz subasocijaciju typ- icum, koja je karakteristična za srednji i južni dio areala pridolaska, u sjevernom dijelu areala razvijena je i subasocijacija carpinetosum orientalis.

Iz Šumskogospodarske osnove područja (ŠGOP, 2016.2025.) nalazimo da ukupna površina uređajnog razreda panjača hrasta crnike u Republici Hrvatskoj iznosi 21 216,63 ha, od toga je 8351,79 ha u redovitom gospodarenju poduzeća „Hrvatske šume“ d.o.o., Zagreb, površina od 12 740,18 ha nalazi se u privatnim šumama, dok površinom od 124,66 ha gospodare ostali pravni subjekti.

\section{Ekološki zahtjevi}

Šumama hrsta crnike odgovara plitko, suho tlo na vapnencu (crvenica i smeđe tlo) ili na flišu, a u toplijim područjima (Korzika, Maroko, Alžir) pojavljuje se i na drugim geološkim podlogama. Hrast crnika je kserofilna i termofilna vrsta koja je otporna na suha sredozemna ljeta i jaku insolaciju. Zahvaljujući i posebnim prilagodbama koje se odnose na njen oblik (kožasto i dlakavo lišće, uvučene puči, široka korijenova mreža), te fiziološki aparat. Alexandrian (1992) navodi u svezi s prilagođenosti aridnim uvjetima vrlo dubok glavni korijen i razvijeno postrano korijenje koje se čvrsto veže u tlu i pukotinama krške podloge. U mladosti sporo raste, postižući oko pete godine života visinu od $1 \mathrm{~m}$, a oko 50 godine $10-12 \mathrm{~m}$ visine i $30-40 \mathrm{~cm}$ debljinskog prirasta. Sa 100 godina prirast u visinu i debljinu znatno pada.

Crnika u mlađoj dobi podnosi zasjenu, dok starija stabla trebaju puno svjetla (heliofilna vrsta). Biljci najbolje odgovara južna ekspozicija, posebno kada raste u hladnijem području svojega areala. Inače može rasti s dobrim uspjehom na svim ekspozicijama. Izbjegava strmine, iako nije rijetka na velikim nagibima. Vrlo je otporna na jak ujecaj vjetra (u našim uvjetima na buru i jugo), na utjecaj posolice i raste uz samu morsku obalu. Najčešća $\mathrm{pH}$ vrijednost na tlima na kojima dolazi ova vrsta je između 6 i 7,5. Vlaga u tlu je ograničavajući čimbenik, jer utječe na klijanje i opstanak mladih biljaka crnike prvih godina. Nakon toga bitan je zajednički utjecaj svjetla i vlage u tlu. Postupno otvaranje sklopa omogućuje razvoj pomlatka i sprječava jače širenje agresivnijih vrsta pratilica. U suprotnom potpuno otvaranje sklopa ne odgovara intenzivnijem rastu i razvoju crnike. Razlog je osjetljivost ponika na izravnu sunčevu svjetlost uz povećano isušivanje u površinskom horizontu tla. Prpić (1986) je utvrdio da relativna užitna svjetlost od 15\% nije dovoljna za razvoj stabalaca crnike jer dolazi do stagnacije visinskog prirasta i sušenja. Na to ukazuju i istraživanja Krejčija i Dubravca (2004) i Dubravca i dr. (2018).

Na niske temperature crnika je najosjetliivija u fazi klijanja. Dovoljno je da temperatura padne na -2 do $-3{ }^{\circ} \mathrm{C}$ pa da dođe do oštećivanja vitalnih dijelova mladih biljčica. Prema tome, može se zaključiti da je prirodno širenje crnike onemogućeno na svim onim mjestima na kojima se tem- 
peratura klijanja biljke spušta samo nekoliko celzijevih stupnjeva ispod nule, pa makar ostali ekološki uvjeti bili i povoljni. Prema Embergeru (1955) crniku nalazimo od hladnih polusuhih do umjerenih humidnih bioklimatskih područja. U optimalnim uvjetima podneblja tvori čiste sastojine visokog uzgojnog oblika; nažalost radi stoljetnog antropogenog utjecaja takve sastojine su vrlo rijetke.

Uvjeti podneblja koji određuju rasprostiranje hrasta crnike prema (Forestry Compendium, 2000): visinska rasprostranjenost: 0 - $2900 \mathrm{~m}$, srednja godišnja količina oborina: 300
- 1500 mm, kišno razdoblje: bimodalno, trajanje sušnog razdoblja: do dva mjeseca tijekom ljeta, srednja godišnja temperatura: $\left(10-20^{\circ} \mathrm{C}\right)$, srednja maksimalna temperatura najtoplijeg mjeseca: $\left(28-33^{\circ} \mathrm{C}\right)$, srednja minimalna temperatura najhladnijeg mjeseca: $\left(-3-8^{\circ} \mathrm{C}\right)$, apsolutna minimalna temperatura: $\left(-23^{\circ} \mathrm{C}\right)$.

Česmina kao grm i posebice kao ukrasna biljka ima posebno mjesto u vrtnoj arhitekturi priobalja i otoka. U hortikulturi se uspješno rabi kao soliter, ali i u grupimičnoj strukturi u parkovima čistog i mješovitog karaktera.
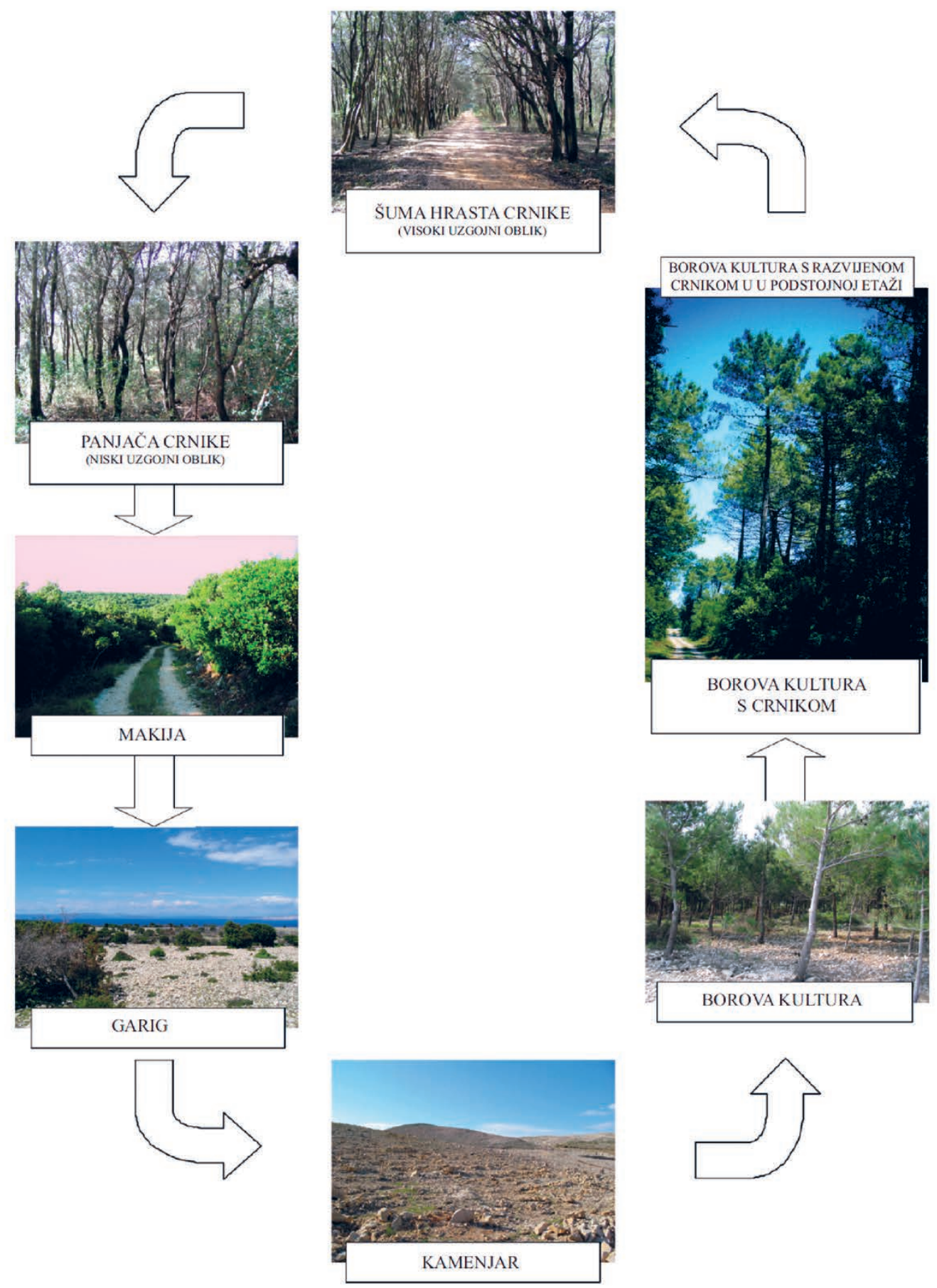

Slika 1. Sukcesijski procesi (regresija i progresija) u šumama hrasta crnike u eumediteranu (Foto: D.Barčić); u Barčić et al. (2011) Figure 1. Successive processes (regression and progression) in holm oak forests in the eumediterranean (Photo: D.Barčić); in Barčić et al. (2011) 
Tijek razvoja vegetacije u smislu progresije i regresije prikazan je sukcesijom crnikovih šuma (slika 1). Slika ukazuje na vremenski dugo razdoblje koje je potrebno tijekom sukcesije šumske vegetacije, posebno u slučaju progresivne sukcesije i potpune konverzije vrsta. Naime, radi se najmanje o nekoliko ophodnji borovih kultura, te izravnoj povezanosti sa stanišnim uvjetima. Trajanje jedne ophodnje može biti propisano u granicama od 60 do 80 godina. Bitno je naglasiti kako prijelaz, tj. konverziju vrsta u borovoj kulturi nije jednostavno ostvariti samo jednim zahvatom. Radi se ponajprije o ispunjavanju osnovnih preduvjeta. Prvi se odnosi na intenzivnu pojavu hrasta crnike, posebice mladih stabala i nakon toga opreznom otvaranju sastojine u nekoliko navrata. U slučaju dovršnog sijeka borova na kraju ophodnje velika količina svjetla više će pogodovati pratilicama i agresivnijim vrstama, što svakako nije povoljno za crniku. Stoga uspjeh sukcesijskih procesa u melioracijskom smislu ovisi o nizu biotskih i abiotskih čimbenika. Pozitivan utjecaj može se očekivati provođenjem šumsko-uzgojnih radova njege i proredama tijekom ophodnje u borovoj kulturi. Ta skupina radova može povoljno utjecati na sastojinu u kvalitativnom smislu i manjem riziku od nastanka šumskog požara, a istovremeno će omogućiti intenzivniji rast i razvoj klimazonalne vegetacije listača.

Uz sliku 1 treba pojasniti kako u svakom stadiju dolazi do promjene u zastupljenosti pojedinih vrsta, jer se mijenjaju i stanišni uvjeti.

Panjača je u gospodarsko-ekološkom smislu šuma niskog uzgojnog oblika koja zadržava proizvodnu sposobnost tla u uvjetima podneblja. U panjači dominiraju hrast crnika i crni jasen, dok su ostale pratilice zastupljene ovisno o svjetlu (intenzivnije na rubovima) koje ulazi u sastojinu. Stanišni uvjeti uz antropogeni utjecaj određuju smjer razvoja panjače prema visokom uzgojnom obliku ili prema makiji. Prva istraživanja u panjači na otoku Rabu putem devet pokusnih ploha proveo je profesor Šumarskog fakulteta u Zagrebu Andrija Petračić 1934. godine. Istraživanja su obnovljena na istim plohama 1974. godine (Matić i Rauš, 1986).

Makija (tal. macchia, fran. maquis, špa. monte bajo, por. mato) je postankom dio crnikove šume. Devastacijom šumske vegetacije i degradacijom šumskog tla razvija se iz panjeva posječenih stabala crnike. U makiji nije izražena slojevitost i sklop je vrlo gust. Visoka je do nekoliko metara i u njoj prevladavaju grmoliki oblici hrasta crnike, crnog jasena, planike, zelenike, lemprike, velikog vrijesa i drugih vrsta. Balen (1935) navodi za makiju tri razvojna stupnja. I. boniteta gdje je visina preko 8 metara, zatim II. boniteta visine od 2 do 8 metara i III. boniteta do 2 metra visine. Za nastajanje makije isti autor navodi određene čimbenike. Biotske kada je iskorištavanje u većoj mjeri nego što je u stanišnim uvjetima moguće, zatim edafske gdje se radi o smanjenoj proizvodnosti i plodnosti te izloženosti eroziji, što je posljedica prethodnih čimbenika. Na kraju bitan je utjecaj i klimatskog čimbenika (sušno razdoblje i evapotranspiracija). Istraživanja u makiji s ciljem konverzije u viši uzgojni oblik provedena su u predjelu Kalifront 1977. godine (Rauš, 1978). Različitim intenzitetima prorede istraživan je utjecaj na ubrzavanje procesa prirodnog pomlađivanja. Provedene su prorede slabijeg i jačeg intenziteta na pokusnim plohama, a istovremeno je određena i kontrolna ploha. Obavljena je i sjetva žira crnike pod motiku na plohi s jačim intenzitetom prorede. Rezultatima su autori utvrdili da je pojava pomlatka hrasta crnike na pokusnim plohama neovisna o intenzitetu sječe i njege. Na kontrolnoj plohi u makiji također se javio obilan pomladak koji se kasnije nije razvio vjerojatno zbog nedostatka svjetla. Istraživanjem je zaključeno da u gustim sastojinama gdje svjetlo izravno ne dopire do tla ima više vlage dovoljne za klijanje, ali i za samo početni razvoj pomlatka.

Garig je također postankom dio crnikove šume. Nastavljanjem devastacije vegetacije ili regresijskih procesa u makiji dolazi do njenog prorjeđivanja. Mogu se razlikovati garizi s obrastom ispod normalnog $(0,4-0,7)$, zatim sa slabim obrastom $(0,3-0,5)$ i razbijeni garizi s vrlo slabim obrastom ispod 0,3. Procesi se odnose na česte i nekontrolirane sječe, intenzivnu ispašu stoke, što se povezuje s uvjetima podneblja u kojima je onemogućena ili znatno usporena obnova šumske vegetacije. $\mathrm{U}$ odnosu prema panjači i makiji radi manje pokrovnosti i razbijene strukture pojavljuju se druge rezistentne vrste. Radi se o heliofilnim i termofilnim vrstama: šmrika (Juniperus oxycedrus L.), somina (Juniperus phoenicea L.), crveni bušin (Cistus incanus L.), bijeli bušin (Cistus salviefolius L.), ljeplijivi bušin (Cistus monspeliensis L.), kretski bušin (Cistus creticus L.), opasna hlapinika (Calicotome infesta (Pres.) Guss.), vlasnata hlapinika (Calicotome villosa (Poir.) Lk.), veliki vrijes (Erica arborea L.), brnistra (Spartium junceum L.), ružmarin (Rosmarinus officinalis L.) i druge vrste. Značajno je napomenuti da u garizima rastu mnoge aromatične vrste. Garizi se razvijaju na umjererno degradiranim površinama, a plitko tlo $s$ većim udjelom kamenog materijala povećava opasnost od vodene i eolske erozije.

Kamenjar je završni stadij u regresijskom procesu crnikovih šuma u eumediteranu. Uzroci nastanka su različiti, od snažnih oblika erozije, zatim intenzivne ispaše i požara u uvjetima podneblja na kršu. Tlo na kojem se razvija izuzetno je plitko i skeletno. Kamenjari se često koriste kao pašnjaci, stoga je svaka obnova vegetacije bez korištenja pionirskih vrsta dugotrajna i vrlo zahtjevna. Vrste koje rastu u takvim uvjetima imaju veliku količinu eteričnih ulja i sposobnost prilagodbe na nepovoljne stanišne uvjete. Najčešće vrste kamenjara su: ljekovita kadulja (Salvia officinalis L.), smilje (Helichrysum italicum (Roth) D.Don), primorski vrisak (Satureja montana (Host) Nyman), mekinjak (Drypis spinosa L.), pustenasti dubačac (Teucrium polium L.), šmrika (Juniperus oxycedrus L.) i druge vrste. 


\section{CILJEVI ISTRAŽIVANJA RESEARCH GOALS}

Hrast crnika prepoznatljiva je vrsta sredozemnog (jadranskog) područja u Hrvatskoj. Tijekom dugog razdoblja znanstvenici sa Šumarskog fakulteta istraživali su šume hrasta crnike. U radu je predstavljen prikaz, analiza i sinteza prijašnjih i sadašnjih istraživanja samo na trajnim pokusnim plohama (slika 2). Za obrade i analize korištene su ranije napravljene fitocenološke snimke. $S$ ciljem pregleda istraživanja na trajnim pokusnim plohama u radu je prikazano i istraživanje zapaljivosti i gorivosti hrasta crnike, a uzorkovanje je obavljeno na svim pokusnim plohama koje se nalaze na otoku Rabu. Naime, problem šumskih požara izravno je povezan s utjecajem na šumsku vegetaciju. Stoga je analiza mediteranskih vrsta, u ovom slučaju hrasta crnike važna za pitanja većeg ili manjeg rizika od nastanka ili širenja požara otvorenog prostora. Vegetacijska istraživanja na trajnim pokusnim plohama nastavljaju se i danas, a kroz dosadašnju analizu u radu se prikazuje temeljni smjer ovih istraživanja: praćenje sukcesije vegetacije i odnos vegetacije prema požarima.

\section{MATERIJAL I METODE MATERIAL AND METHODS}

Istraživanje flornog sastava uključivalo je izradu vegetacijskih snimaka na trajnim pokusnim plohama i na pokusnim plohama izdvojenim za istraživanja po standardnoj srednjeeuropskoj metodi ciriško-monpelješke škole (BraunBlanquet, 1964.; Westhof i van der Maarel 1973.). Vegetacijsko snimanje obuhvaća popis svih biljnih vrsta u sloju drveća, grmlja i prizmenog raslinja koje su uočene i zabilježene na odabranim plohama s pripadajućim vrijednostima za abundaciju (broj) i pokrovnost. Plohe su postavljene u šumskoj zajednici hrasta crnike i crnog jasena (Fraxino orni-Quercetum ilicis Horvatić/1956/1958).

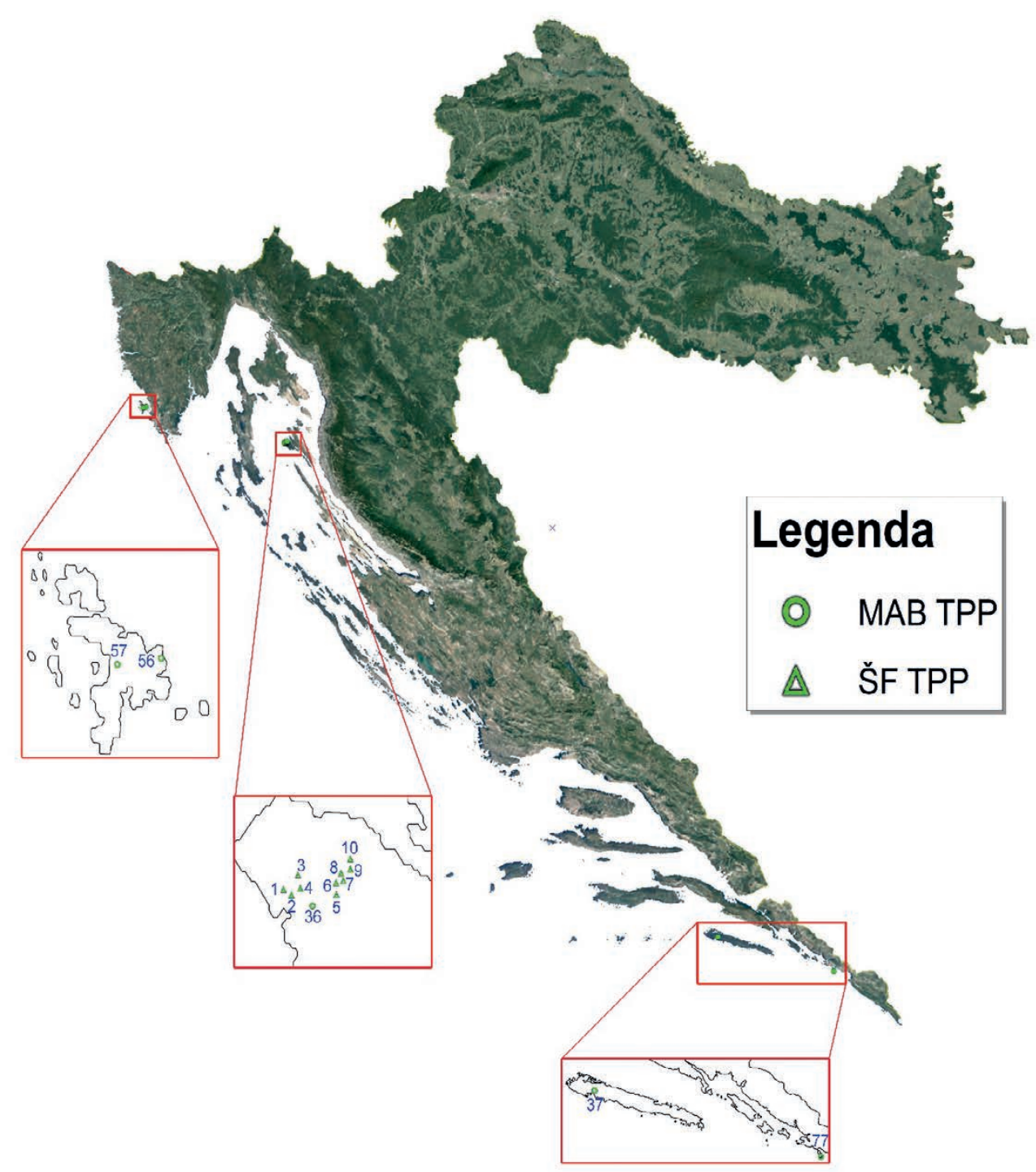

Slika 2. Prikaz trajnih pokusnih ploha na istraživanom području

Figure 2 Display of permanent experimental plots in the field of research 
Istraživanjem su obuhvaćene samo MAB plohe (Šegulja i Rauš, 1993) i plohe na otoku Rabu na poluotoku Kalifrontu (slika 2) osnivane istraživanjima Rauša, Španjola i Barčića (plohe Šumarskog fakulteta). U rezultatima nisu prikazane vegetacijske snimke sa svih deset pokusnih ploha na otoku Rabu nego su izdvojene četiri pokusne plohe gdje su ponavljana istraživanja (Tablice 6 i 7).

Za određivanje zapaljivosti i gorivosti hrasta crnike uzimani su uzorci sa deset trajnih pokusnih ploha Šumarskog fakulteta na otoku Rabu i korištena je višefaktorska analiza varijance, prema Sokal i Rohlf (1995). U slučaju statistički značajne razlike za neki od promatranih faktora ili interakcija Tukeyevim post hoc testom testirano je tko čini tu razliku. Za odnos pojedinih varijabli korištena je linearna korelacijska analiza. Da bi utvrdili povezanost LFMC (sadržaj vlage živog goriva), srednje mjesečne zračne vlage, srednje mjesečne temperature zraka, srednje mjesečne maksimalne temperature zraka, srednje mjesečne minimalne temperature zraka i srednje mjesečne količine oborina (nezavisne varijable). Sve statističke analize napravljene su koristeći statističke pakete SAS i STATISTICA 7.1 (Clausen, 1998; SAS Institute Inc., 1999; StatSoft, Inc., 2007).

\section{REZULTATI}

\section{RESULTS}

\section{Vegetacijske značajke - Vegetation characteristics}

Šumska vegetacija otoka Raba najvećim dijelom pripada šumskoj zajednici hrasta crnike i crnoga jasena (Fraxino orni-Quercetum ilicis Horvatić/1956/1958) koja je najraširenija na Jadranu. Prema Trinajstiću (1985) granica između vazdazelene i listopadne vegetacije nije oštra uslijed antropogenim utjecajem izmijenjenih uvjeta. Florni sastav šume hrasta crnike i crnog jasena ovisi o strukturnim značajkama sastojine u kojima se nalaze vazdazelene vrste iz reda Quercetalia ilicis i listopadne vrste iz reda Quercetalia pubescentis (Rauš, 1986 i Španjol 1995).

Prema posljednjim istraživanjima vegetacije iz 2017. godine koje je radio Španjol (rukopis) stanje na trajnoj pokusnoj plohi broj 36 na otoku Rabu je prikazano u tablici 1. U tablici 1 su prikazana i početna istraživanja Rauša i Španjola (rukopis). Osobito su vrijedna istraživanja crnikovih šuma na trajnim pokusnim plohama. Te plohe dio su međunarodnog projekta "Čovjek i biosfera" (Man and Biosphere, $M A B)$ pod pokroviteljstvom Organizacije Ujedninjenih naroda za obrazovanje, znanost i kulturu (United Nations Educational, Scientific and Cultural Organization, UNESCO). Naime, podrazumijeva se da se na tim istim plohama provode trajna praćenja stanja i dugotrajna znanstvena istraživanja šumskog ekološkog sustava. Vegetacijska istraživanja u crnikovim šumama mogu se usporediti na trajnim pokusnim plohama (MAB) s otoka Raba, Brijuna,
Tablica 1. Vegetacijske snimke na trajnoj pokusnoj plohi broj 36 na otoku Rabu

Table 1. Vegetation relevés on permanent experimental plot number 36 on the island of Rab

\begin{tabular}{|c|c|c|c|c|}
\hline Broj plohe & \multicolumn{4}{|c|}{ TPP 36} \\
\hline Lokalitet & \multicolumn{4}{|c|}{ NPŠO Rab } \\
\hline Veličina snimke & \multicolumn{4}{|c|}{$20 \times 20 \mathrm{~m}$} \\
\hline Sastojina & \multicolumn{4}{|c|}{$\begin{array}{l}\text { Fraxino orni-Quercetum ilicis typicum } \\
\text { H-ić (1956)1958 }\end{array}$} \\
\hline Nadmorska visina & \multicolumn{4}{|c|}{$30-65 \mathrm{~m}$} \\
\hline |zloženost & \multicolumn{4}{|c|}{ jugozapadna } \\
\hline Matični supstrat & \multicolumn{4}{|c|}{ vapnenac } \\
\hline Nagib & \multicolumn{4}{|c|}{ ravno } \\
\hline Godina & 1983. & 1999. & 18.6.2013. & 6.4 .2017 \\
\hline Pokrovnost & $100 \%$ & & $100 \%$ & $100 \%$ \\
\hline Sloj drveća & $90 \%$ & & $95 \%$ & $95 \%$ \\
\hline Sloj grmlja & $30 \%$ & & $15 \%$ & $25 \%$ \\
\hline Prizemni sloj & $50 \%$ & & $2 \%$ & $<1 \%$ \\
\hline Vrsta & \multicolumn{4}{|c|}{ Procjena } \\
\hline
\end{tabular}

\section{I - Sloj drveća}

Quercus ilex L.

Fraxinus ornus $\mathrm{L}$.

Phillyrea latifolia L.

Viburnum tinus $\mathrm{L}$.

Arbutus unedo L.

Erica arborea L.

II - Sloj grmlja

Quercus ilex L.

Fraxinus ornus $\mathrm{L}$.

Phillyrea latifolia L.

Viburnum tinus $\mathrm{L}$.

Arbutus unedo $\mathrm{L}$.

Laurus nobilis $\mathrm{L}$.

Pistacia lentiscus L.

Crataegus transalpina $L$.

Erica arborea L.

Smilax aspera L.

Ruscus aculeatus $\mathrm{L}$.

III - Sloj prizemnog rašća

Quercus ilex L.

Fraxinus ornus $\mathrm{L}$.

Ruscus aculeatus $\mathrm{L}$.

Viburnum tinus $\mathrm{L}$.

Pistacia lentiscus L.

Erica arborea L.

Arbutus unedo L.

Phillyrea latifolia L.

Rubus ulmifolius Schott.

Asparagus acutifolius L.

Smilax aspera L.

Tamus communis $\mathrm{L}$.

Rubia peregrina L.

Clematis flammula L.

Cyclamen repandum $\mathrm{L}$.

Rosa sempervirens $L$.

Lonicera implexa $\mathrm{L}$.

Hedera helix L.

Viola odorata L.

Brachypodium ramosum (L) R.S.
4

1

4

$+$

$+$

$+$

1

1

1

1

1
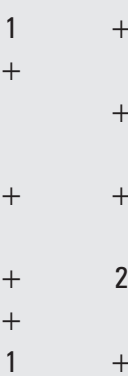

1

$+$
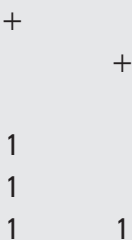

$+$

$+$

$+$ 
Tablica 2. Vegetacijske snimke na trajnoj pokusnoj plohi broj 56 na Brijunima

Table 2. Vegetation relevés on permanent experimental plot number 36 on the island of Brijuni

\begin{tabular}{|c|c|c|c|}
\hline Broj plohe & \multicolumn{3}{|c|}{ TPP 56} \\
\hline Lokalitet & \multicolumn{3}{|c|}{ Mrtvi vrh } \\
\hline Veličina snimke & \multicolumn{3}{|c|}{$400 \mathrm{~m}^{2}$} \\
\hline Sastojina & \multicolumn{3}{|c|}{$\begin{array}{l}\text { Fraxino orni-Quercetum ilicis typicum } \\
\text { H-ić (1956)1958 }\end{array}$} \\
\hline Nadmorska visina & \multicolumn{3}{|c|}{$10-15 \mathrm{~m}$} \\
\hline |zloženost & \multicolumn{3}{|c|}{ SI } \\
\hline Matični supstrat & \multicolumn{3}{|c|}{ vapnenac } \\
\hline Nagib & \multicolumn{3}{|c|}{$-1 \%$} \\
\hline Datum & 17.2.1988. & 8.5.2017. & 8.5.2017 \\
\hline \multicolumn{4}{|l|}{ Pokrovnost } \\
\hline Sloj drveća & $100 \%$ & $90 \%$ & $90 \%$ \\
\hline Sloj grmlja & $30 \%$ & $2 \%$ & $2 \%$ \\
\hline Prizemni sloj & $5 \%$ & $<1 \%$ & $<1 \%$ \\
\hline Vrsta & \multicolumn{3}{|c|}{ Procjena } \\
\hline
\end{tabular}

\section{I - Sloj drveća}

Quercus ilex L.

Laurus nobilis $\mathrm{L}$.

Fraxinus ornus $\mathrm{L}$.

Phillyrea latifolia L.

II - Sloj grmlja

Quercus ilex $\mathrm{L}$.

Laurus nobilis $\mathrm{L}$.

Fraxinus ornus $\mathrm{L}$.

Phillyrea latifolia L.

III - Sloj prizemnog rašća

Laurus nobilis $\mathrm{L}$.

Quercus ilex L.

Cyclamen repandum $\mathrm{Sm}$.

Fraxinus ornus $\mathrm{L}$.

Rubia peregrina $\mathrm{L}$.

Urtica dioica $\mathrm{L}$.

Viola sp.

otoka Mljeta i otoka Lokruma (TPP br.36, br. 56 i 57, br. 37, br. 77). Također, situacija na ostalim trajnim pokusnim plohama s otoka Raba upućuje na činjenicu postupne progresivne sukcesije s time da je na otoku Rabu izrazito negativan utjecaj divljači na prizemno raslinje (Tablice 6 i 7).

Smanjenje broja vrsta u sloju grmlja i prizemnog raslinja (ako se usporedi s ranijim snimkama Rauša, 1986 i Španjola, 1995) uglavnom se može pripisati i štetnom utjecaju krupnih preživača - muflona (Ovis ammon L.) i u manjoj mjeri jelena aksisa (Axis axis Erx.) s obzirom da se trajna pokusna ploha nalazi unutar Državnog lovišta VIII/6 „Kalifront“ kojim upravlja Šumarski fakultet. Bitna činjenica je da se vjerojatno radi o prevelikom broju divljači po jedinici po-
Tablica 3. Vegetacijske snimke na trajnoj pokusnoj plohi broj 57 na Brijunima

Table 3. Vegetation relevés on permanent experimental plot number 57 on the island of Brijuni

\begin{tabular}{|c|c|c|c|}
\hline Broj plohe & \multicolumn{3}{|c|}{ TPP 57} \\
\hline Lokalitet & \multicolumn{3}{|c|}{ Bijela vila (Turanj) } \\
\hline Veličina snimke & \multicolumn{3}{|c|}{$400 \mathrm{~m}^{2}$} \\
\hline Sastojina & \multicolumn{3}{|c|}{$\begin{array}{l}\text { Fraxino orni-Quercetum ilicis typicum } \\
\text { H-ić (1956)1958 }\end{array}$} \\
\hline Nadmorska visina & \multicolumn{3}{|c|}{$15-20 \mathrm{~m}$} \\
\hline Izloženost & \multicolumn{3}{|c|}{$\mathrm{JZ}$} \\
\hline Matični supstrat & \multicolumn{3}{|c|}{ vapnenac } \\
\hline Nagib & \multicolumn{3}{|c|}{$1-3 \%$} \\
\hline Datum & 10.2.1988. & 9.5.2017. & 9.5.2017. \\
\hline \multicolumn{4}{|l|}{ Pokrovnost } \\
\hline Sloj drveća & $95 \%$ & $95 \%$ & $90 \%$ \\
\hline Sloj grmlja & $75 \%$ & $70 \%$ & $60 \%$ \\
\hline Prizemni sloj & $35 \%$ & $25 \%$ & $30 \%$ \\
\hline Vrsta & \multicolumn{3}{|c|}{ Procjena } \\
\hline
\end{tabular}

\section{I - Sloj drveća}

Quercus ilex L.

Laurus nobilis $\mathrm{L}$.

Phillyrea latifolia L.

Fraxinus ornus $\mathrm{L}$.

Arbutus unedo $\mathrm{L}$.

\section{II - Sloj grmlja}

Laurus nobilis $L$.

Ruscus aculeatus L.

Phillyrea latifolia L.

Viburnum tinus $\mathrm{L}$.

Arbutus unedo $\mathrm{L}$.

Smilax aspera $L$.

Pistacia lentiscus $L$.

Rhamnus alaternus $L$.

Myrtus communis L.

Rosa sempervirens $\mathrm{L}$.

Erica arborea L.

Quercus ilex L.

\section{III - Sloj prizemnog rašća}

Laurus nobilis L.

Arum italicum Mill.

Ruscus aculeatus L.

Viburnum tinus $\mathrm{L}$.

Brachypodium ramosum (L) R.S

Phillyrea latifolia L.

Asparagus acutifolius L.

Rubus ulmifolius Schott.

Quercus ilex L.

Smilax aspera L.

Fraxinus ornus $\mathrm{L}$.
4
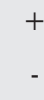

$$
+
$$

2

1

$+$$$
1
$$ 
Tablica 4. Vegetacijske snimke na trajnoj pokusnoj plohi broj 37 na otoku Mljetu

Table 4. Vegetation relevés on permanent experimental plot number 37 on the island of Mljet

\begin{tabular}{|c|c|c|c|}
\hline Broj plohe & \multicolumn{3}{|c|}{ TPP 37} \\
\hline Lokalitet & \multicolumn{3}{|c|}{ Velika Dolina } \\
\hline Površina & \multicolumn{3}{|c|}{$20 \times 20 \mathrm{~m}$} \\
\hline Sastojina & \multicolumn{3}{|c|}{ Rezervat šumske vegetacije } \\
\hline Nadmorska visina & \multicolumn{3}{|c|}{ oko 300 m } \\
\hline Izloženost & \multicolumn{3}{|c|}{ sjever-sjeverozapad } \\
\hline Matični supstrat & \multicolumn{3}{|c|}{ vapnenac } \\
\hline Nagib & \multicolumn{3}{|c|}{$20-30 \%$} \\
\hline Datum & 1981. & 1995. & 2011. \\
\hline Pokrovnost & $95 \%$ & $95 \%$ & $95 \%$ \\
\hline Sloj drveća & $95 \%$ & $95 \%$ & $95 \%$ \\
\hline Sloj grmlja & $65 \%$ & $65 \%$ & $65 \%$ \\
\hline Prizemni sloj & $5 \%$ & $5 \%$ & $5 \%$ \\
\hline Vrsta & \multicolumn{3}{|c|}{ Procjena } \\
\hline I - Quercus ilex L. & 5 & 5 & 5 \\
\hline Phylirea latifolia L. & - & 1 & - \\
\hline Laurus nobilis L. & - & + & - \\
\hline II - Phillyrea angustifolia L. & - & 2 & 2 \\
\hline Erica arborea L. & + & + & - \\
\hline Arbutus unedo L. & + & - & - \\
\hline Rhamnus alaternus $\mathrm{L}$. & + & - & - \\
\hline Quercus ilex L. & + & - & - \\
\hline Laurus nobilis L. & + & 1 & - \\
\hline Viburnum tinus $\mathrm{L}$. & 3 & 3 & 2 \\
\hline Ruscus aculeatus L. & - & 2 & 1 \\
\hline Smilax aspera L. & 2 & - & + \\
\hline Rosa sempervirens L. & + & - & + \\
\hline Myrtus communis L. & + & 1 & + \\
\hline Pistacia terebinthus & - & + & - \\
\hline Fraxinus ornus $\mathrm{L}$. & - & + & - \\
\hline III - Viburnum tinus L. & - & 2 & + \\
\hline Dryopteris oreopteris & + & - & - \\
\hline Rubia peregrina L. & + & 1 & - \\
\hline Ruscus aculeatus L. & 1 & + & + \\
\hline Phillyrea latifolia L. & - & + & + \\
\hline Cyclamen repandum S.S. & - & 2 & 2 \\
\hline Hedera helix L. & + & + & + \\
\hline Thamus communis $\mathrm{L}$. & - & + & + \\
\hline Quercus ilex L. & - & + & + \\
\hline Carex sp. & - & + & - \\
\hline Geranium robertianum L. & - & + & - \\
\hline Tamus communis $\mathrm{L}$. & - & + & - \\
\hline Rosa sempervirens L. & + & - & - \\
\hline Pteridium aquilinum (L.)Kuhn & - & - & + \\
\hline
\end{tabular}

Tablica 5. Vegetacijske snimke na trajnoj pokusnoj plohi broj 77 na otoku Lokrumu

Table 5. Vegetation relevés on permanent experimental plot number 77 on the island of Lokrum

\begin{tabular}{|c|c|c|}
\hline Broj plohe & \multicolumn{2}{|c|}{ TPP 77} \\
\hline Lokalitet & \multicolumn{2}{|c|}{ Šarlotin zdenac } \\
\hline Površina & \multicolumn{2}{|c|}{$20 \times 20 \mathrm{~m}$} \\
\hline Sastojina & \multicolumn{2}{|c|}{$\begin{array}{l}\text { Fraxino orni-Quercetum ilicis } \\
\text { typicum H-ić (1956)1958 }\end{array}$} \\
\hline Nadmorska visina & \multicolumn{2}{|c|}{$18 \mathrm{~m}$} \\
\hline Izloženost & \multicolumn{2}{|c|}{ sjeveroistok } \\
\hline Nagib & \multicolumn{2}{|c|}{$5-10 \%$} \\
\hline Matični supstrat & \multicolumn{2}{|c|}{ vapnenac } \\
\hline Datum & 19.02.1987. & 01.06 .2011 \\
\hline Pokrovnost & $100 \%$ & $100 \%$ \\
\hline Sloj drveća & $95 \%$ & $90 \%$ \\
\hline Sloj grmlja & $85 \%$ & $95 \%$ \\
\hline Prizemni sloj & $40 \%$ & $35 \%$ \\
\hline Vrsta & \multicolumn{2}{|c|}{ Procjena } \\
\hline I - Quercus ilex L & 3 & 4 \\
\hline Phillyrea latifolia L. & + & + \\
\hline Arbutus unedo L. & + & + \\
\hline Erica arborea L. & + & + \\
\hline Fraxinus ornus $\mathrm{L}$. & 1 & - \\
\hline Pinus halepensis Mill. & 1 & - \\
\hline Laurus nobilis $\mathrm{L}$. & 1 & 3 \\
\hline II - Phillyrea latifolia L. & 1 & + \\
\hline Arbutus unedo L. & 1 & - \\
\hline Quercus ilex L. & 1 & 2 \\
\hline Erica arborea L. & 1 & - \\
\hline Viburnum tinus $\mathrm{L}$ & 1 & + \\
\hline Myrtus communis $\mathrm{L}$. & 1 & - \\
\hline Ruscus aculeatus L. & 1 & 3 \\
\hline Phillyrea mediaL. & + & - \\
\hline Rubus ulmifolius $\mathrm{L}$. & + & - \\
\hline Laurus nobilis L. & 1 & 4 \\
\hline Rhamnus alaternus $\mathrm{L}$. & + & - \\
\hline Pistacia lentiscus L. & + & - \\
\hline Olea oleaster Hoffmanns. \& Link & + & - \\
\hline Lonicera implexa Aiton & + & - \\
\hline Coronilla emeroides Boiss. & + & - \\
\hline Cistus salviaefolius L. & + & - \\
\hline Rosmarinus officinalis $\mathrm{L}$. & + & - \\
\hline Asparagus acutifolius L. & + & + \\
\hline Smilax aspera L. & 1 & 1 \\
\hline III - Ruscus aculeatus L. & 3 & 2 \\
\hline Rubia peregrina L. & + & 1 \\
\hline
\end{tabular}




\begin{tabular}{lcc} 
Smilax aspera L. & 1 & - \\
Tamus communis L. & + & 1 \\
Quercus ilex L. & 1 & 1 \\
Cyclamen repandum Sm. & + & - \\
Asparagus acutifolius L. & 1 & - \\
Viburnum tinus L. & 1 & - \\
Rubus ulmifolius L. & + & - \\
Hedera helix L. & + & - \\
Laurus nobilis L. & - & 2 \\
Pteridium aquilinum(L.) Kuhn & - & + \\
Celtis australis L. & - & + \\
Geranium purpureum Vill. & + & - \\
Origanum vulgare L. & + & - \\
Teucrium polium L. & + & - \\
Lonicera implexa Aiton & + & - \\
Pistacia lentiscus L. & 1 & - \\
Sesleria autumnalis (Scop.) Schultz & 1 & - \\
Galium lucidum All. & + & - \\
Laurus nobilis L. & + & - \\
Vinca major L. & + & - \\
Teucrium flavum L. & + & - \\
& & - \\
\hline & & - \\
\hline
\end{tabular}

vršine, što negativno utječe na pojavu i brojnost mladih biljaka iz šumske zajednice hrasta crnike i crnoga jasena.

Sukcesijski procesi na trajnim pokusnim plohama izraženi su kroz usporedbu podataka i dugogodišnjeg praćenja stanja. Ukazuju na formiranje strukture sastojine i stvaranje dominantnog sloja drveća (slika 3).

Na slici 3. Q.i. = Quercus ilex, F.o. = Fraxinus ornus, A.u. = Arbutus unedo, V.t. = Viburnum tinus, P.l. = Phyllirea latifolia, E.a. = Erica arborea .

Ukupan broj stabala nešto je veći 2017. nego što je bio 1988. godine. Tome pridonosi velik broj stabala u nižim debljinskim stupnjevima, posebice lovora, što izravno utječe na oblik krivulje strukture sastojine koja ima prijelazni oblik.

\section{Zapaljivost i gorivost hrasta crnike - Flamability and Combustibility of holm oak}

Glavni čimbenik i prijetnja mediteranskoj vegetaciji su ponajprije požari otvorenog prostora. Stoga je na pokusnim plohama otoka Raba, a s obzirom na veći šumski kompleks šuma hrasta crnike napravljena i analiza zapaljivosti i gorivosti. Naime, odnos hrasta crnike prema požaru kao destabilizirajućem čimbeniku u prirodi je ključan za procese poslije požarne obnove vegetacije.

Tablice 6. Vegetacijske snimke na trajnim pokusnim plohama PP1 i PP6 na otoku Rabu Tables 6. Vegetation relevés on permanent experimental plot on the island of Rab

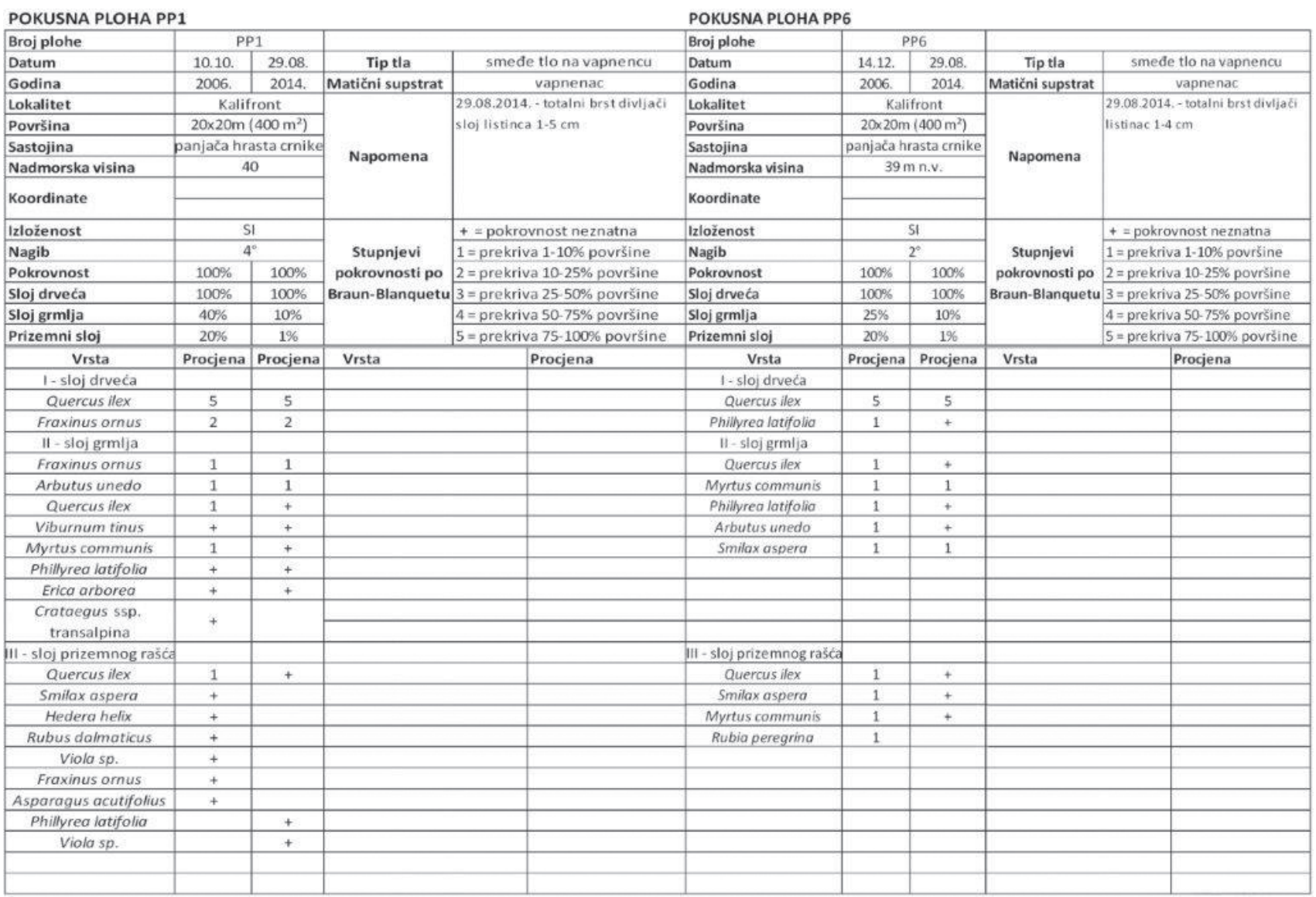


Tablice 7. Vegetacijske snimke na trajnim pokusnim plohama A i $A B C$ na otoku Rabu Tables 7. Vegetation relevés on permanent experimental plot number on the island of Rab

\begin{tabular}{|c|c|c|c|c|c|c|c|c|c|c|}
\hline \multicolumn{5}{|l|}{ POKUSNA PLOHA A } & \multicolumn{6}{|l|}{ POKUSNA PLOHA ABC } \\
\hline \multirow{2}{*}{$\begin{array}{l}\text { Broj plohe } \\
\text { Datum }\end{array}$} & \multicolumn{2}{|c|}{ A } & Tip tla & \multirow{2}{*}{\begin{tabular}{|c|} 
smede tlo na vapnencu \\
vapnenac \\
\end{tabular}} & \multirow{2}{*}{\begin{tabular}{|l} 
Broj plohe \\
Datum
\end{tabular}} & \multicolumn{3}{|c|}{$A B C$ kontrolna } & \multirow[b]{2}{*}{ Tip tla } & \multirow[b]{2}{*}{ smeđe tlo na vapnencu } \\
\hline & 09.10. & 05.07. & Matični supstrat & & & 07.02 & 09.10 & 05.07. & & \\
\hline Godina & 2009. & 2014. & \multirow{6}{*}{ Napomena } & \multirow{2}{*}{$\begin{array}{l}\text { 2009. Ruscus aculeatus potpun } \\
\text { stradala od divljači }\end{array}$} & Godina & 2002. & \multirow{2}{*}{\multicolumn{2}{|c|}{$\frac{2009 . \mid}{K a \text {. }}$}} & Matični supstrat & \multirow{3}{*}{\begin{tabular}{l}
\multicolumn{1}{|c}{ vapnenac } \\
09.10.2009. štete divljači na \\
niskom raslinju
\end{tabular}} \\
\hline Lokalitet & \multicolumn{2}{|c|}{ Kalifront } & & & Lokalitet & \multirow{2}{*}{\multicolumn{3}{|c|}{$\begin{array}{l}\text { Kalifront } \\
20 \times 20 \mathrm{~m}\left(400 \mathrm{~m}^{2}\right)\end{array}$}} & \multirow{5}{*}{ Napomena } & \\
\hline Površina & \multicolumn{2}{|c|}{$20 \times 10 \mathrm{~m}\left(200 \mathrm{~m}^{2}\right)$} & & \multirow{4}{*}{$\begin{array}{l}\text { 2014. divljač ne dopušta da se } \\
\text { stabla izdiferenciraju u viši sloj }\end{array}$} & Pouršina & & & & & \\
\hline Sastojina & panjačah & rasta cnike & & & Sastojina & panjac & ta hrastac & mike & & \multirow[t]{3}{*}{ 2014, veliki utjecaj divljači } \\
\hline Nadmorska visina & \multicolumn{2}{|c|}{$43 \mathrm{~m} n . v$. } & & & Nadmorska visina & \multicolumn{3}{|c|}{$43 \mathrm{mn} \cdot \mathrm{v}$. } & & \\
\hline \multicolumn{3}{|l|}{ Koordinate } & & & \multicolumn{4}{|l|}{ Koordinate } & & \\
\hline Izloženost & & 12 & & $+=$ pokrovnost neznatna & Izloženost & & 12 & & & $+=$ pokrovnost neznatna \\
\hline Nagib & & $0^{\circ}$ & Stupnjevi & 1 = prekriva $1-10 \%$ površine & Nagib & & $0^{\circ}$ & & Stupnjevi & $1=$ prekriva $1-10 \%$ površine \\
\hline Pokrovnost & $100 \%$ & $100 \%$ & pokrovnosti po & $2=$ prekriva $10-25 \%$ površine & Pokrovnost & $100 \%$ & $100 \%$ & $100 \%$ & pokrovnosti po & $2=$ prekriva $10-25 \%$ površine \\
\hline Sloj drueća & $90 \%$ & $90 \%$ & Braun-Blanquetu & $3=$ prekriva $25-50 \%$ površine & Sloj drveća & $90 \%$ & $100 \%$ & $100 \%$ & Braun-Blanquety & $3=$ prekriva $25-50 \%$ površine \\
\hline Sloj grmlja & $75 \%$ & $65 \%$ & & $4=$ prekriva $50.75 \%$ površine & Sloj grmlja & $100 \%$ & $50 \%$ & $70 \%$ & & $4=$ prekriva $50-75 \%$ povrśine \\
\hline Prizemni sloj & $15 \%$ & $1 \%$ & & $5=$ prekriva $75-100 \%$ površine & Prizemni sloj & $20 \%$ & $5 \%$ & $<1 \%$ & & $5=$ prekriva $75-100 \%$ površine \\
\hline Vrsta & Procjena & Procjena & Vrsta & \begin{tabular}{|l|l} 
Procjena \\
\end{tabular} & Vrsta & Procjena & Procjena & Procjens & Vrsta & Procjena \\
\hline 1-sloj drueća & & & & & 1-sloj drveća & & & & & \\
\hline Quercus ilex & 5 & 5 & & & Quercus ilex & 5 & 5 & 5 & & \\
\hline Fraxinus ornus & + & 1 & & & Fraxinus ornus & + & + & + & & \\
\hline Arbutus unedo & 1 & 1 & & & Arbutus unedo & & + & + & & \\
\hline II - sloj grmlja & & & & & II- sloj grmlja & & & & & \\
\hline Quercus ilex & 1 & + & & & Viburnum tinus & + & 3 & 2 & & \\
\hline Arbutus unedo & 1 & 1 & & & Phillyrea media & + & + & + & & \\
\hline Fraxinus omus & + & 1 & & & Erica arborea & + & & & & \\
\hline Phillyrea media & 3 & 2 & & & Quercus ilex & + & + & + & & \\
\hline Erica arborea & + & + & & & Arbutus unedo & + & + & + & & \\
\hline Smilax aspera & & + & & & Rubus daimaticus & + & & & & \\
\hline & & & & & Smilax aspera & 1 & & + & & \\
\hline & & & & & Froxinus ornus & & + & & & \\
\hline III - sloj prizemnog rašca & & & & & III - sloj prizemnog rašća & & & & & \\
\hline Quercus ilex & 1 & + & & & Quercus illex & 1 & + & + & & \\
\hline Fraxinus ornus & + & + & & & Viburnum tinus & 1 & & + & & \\
\hline Phillyrea media & 2 & 2 & & & Fraxinus ornus & + & + & + & & \\
\hline Enica arborea & + & + & & & Smilax aspera & & + & + & & \\
\hline Ruscus aculeatus & & & & & Ruscus aculeatus & + & & & & \\
\hline Viola sp. & & & & & Rubia peregrina & + & & & & \\
\hline & & & & & Erica arborea & & + & & & \\
\hline & & & & & Phillyrea media & & + & & & \\
\hline & & & & & Cyclamen repandum & & & & & \\
\hline & & & & & & & & & & \\
\hline & & & & & & & & & & \\
\hline
\end{tabular}

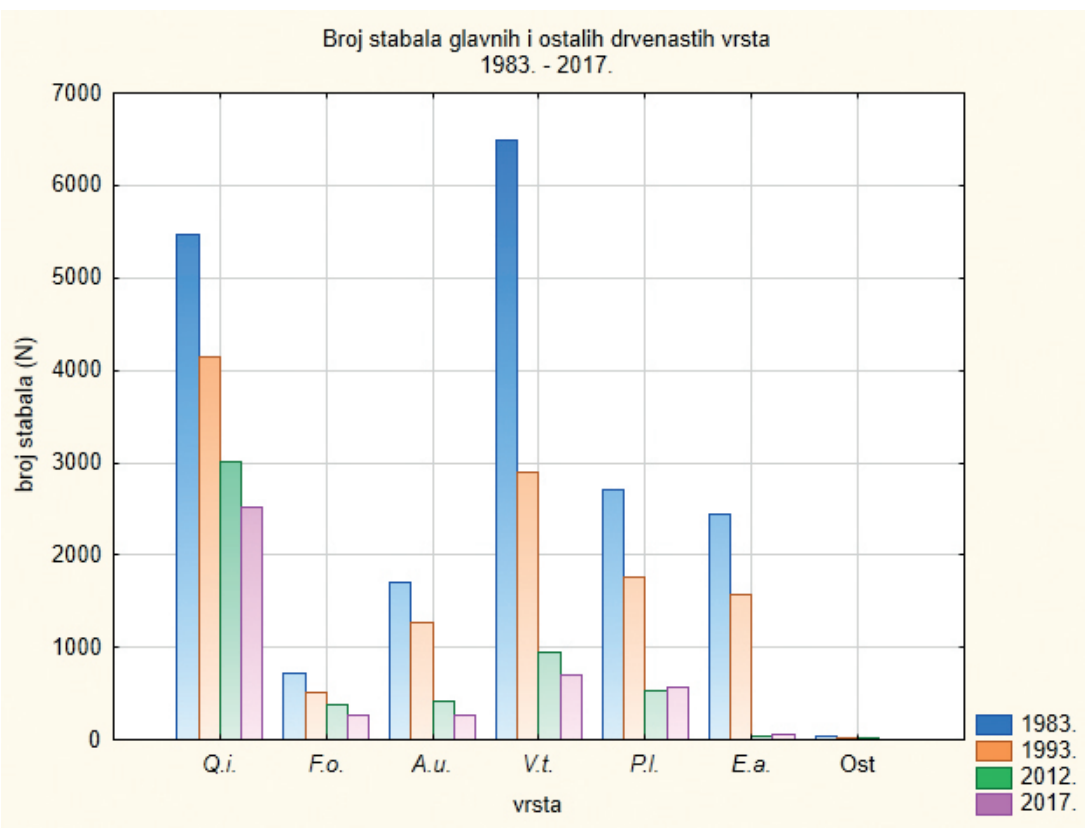

Slika 3. Broj stabala na trajnoj pokusnoj plohi br. 36 na otoku Rabu tijekom izmjera

Figure 3. Number of trees on the permanent experimental plot number 36 on the island of Rab during the survey

Hrast crnika (Quercus ilex L.) temeljna je vrsta u eumediteranskoj zoni priobalnoga vegetacijskog pojasa, gdje se šumski požari učestalo pojavljuju i označeni su kao najvaž- niji prirodni destabilizatori. Različiti su čimbenici koji utječu na zapaljivost i gorivost. Kao najznačajniji označeni su sadržaj vlage goriva (u ovom slučaju list hrasta crnike), 


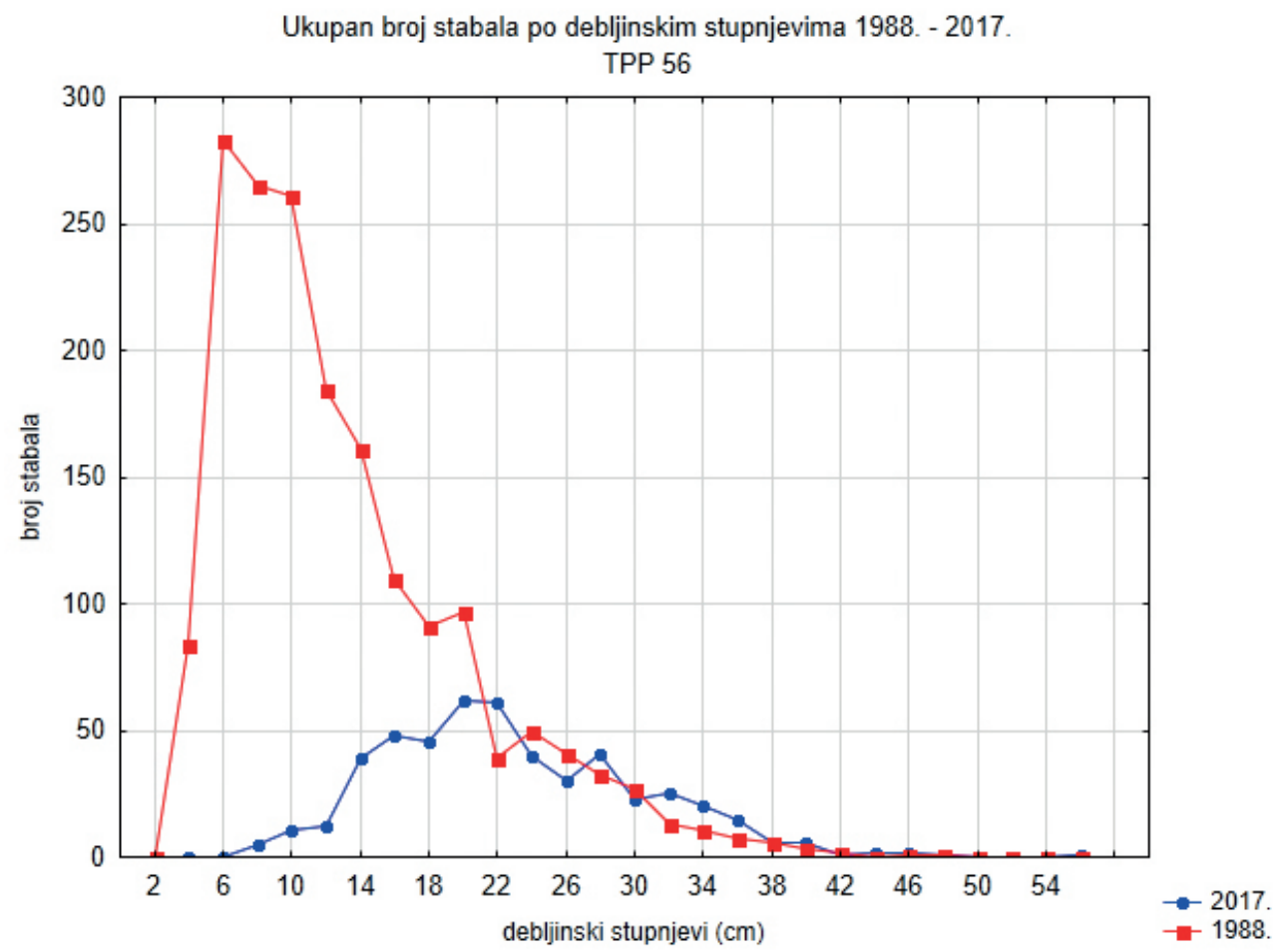

Slika 4. Broj stabala po debljinskim stupnjevima na trajnoj pokusnoj plohi br. 56 na Brijunima tijekom izmjera Figure 4. Number of trees on permanent experimental plot number 56 on the island of Brijuni during survey

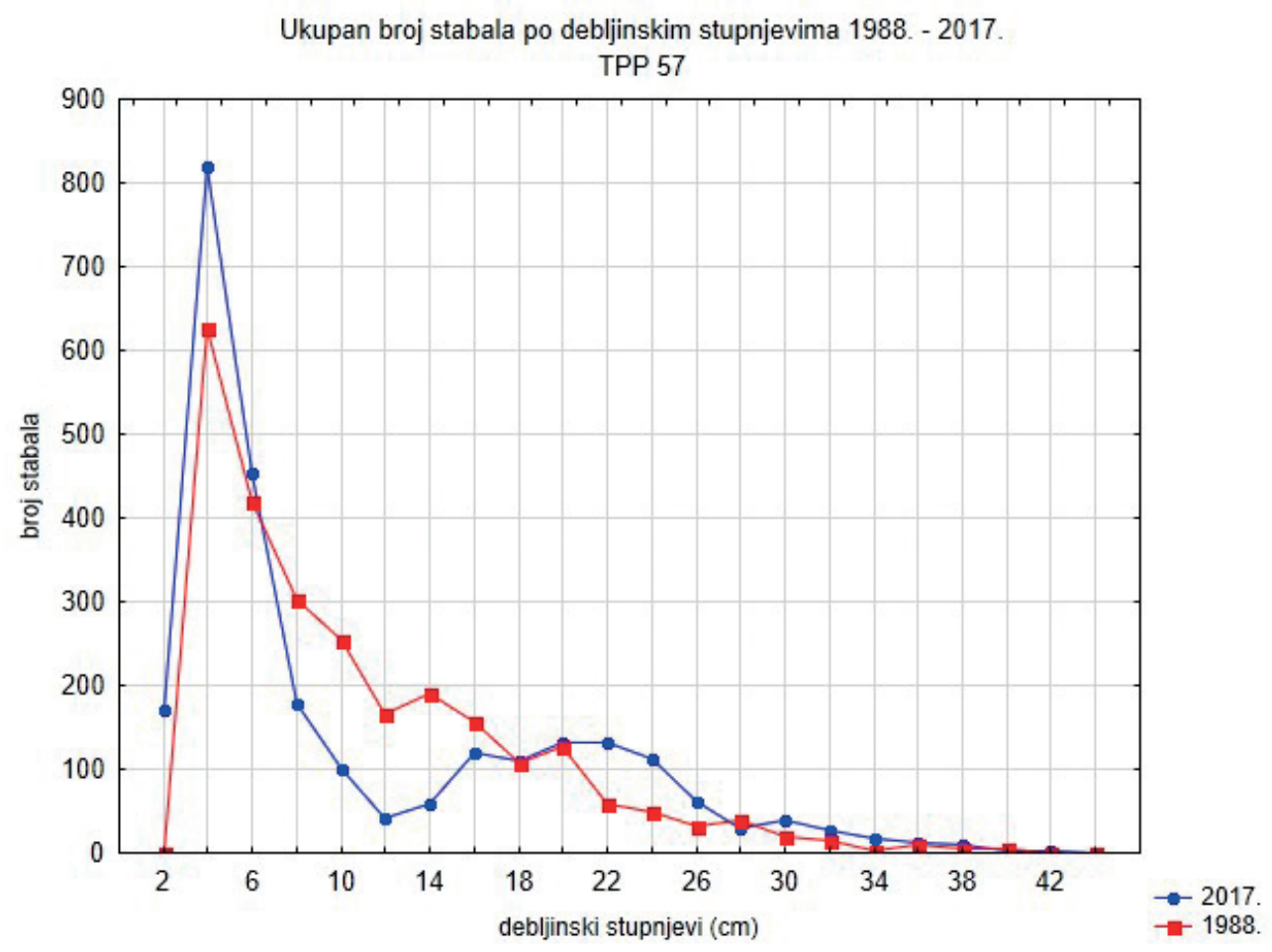

Slika 5. Broj stabala po debljinskim stupnjevima na trajnoj pokusnoj plohi br. 57 na Brijunima tijekom izmjera Figure 5. Number of trees on permanent experimental plot number 57 on the island of Brijuni during survey

srednja mjesečna zračna vlaga, srednja mjesečna temperatura, srednja mjesečna maksimalna i minimalna temperature te srednja mjesečna količina oborina.
$\mathrm{Na}$ tremelju provedene regresijske analize utvrđeno je da statistički značajno na zapaljivost hrasta crnike utječu sadržaj vlage goriva te srednja mjesečna temperatura i srednja 
Tablica 8. Rezultati regresijske analize zapaljivosti kao zavisne varijable za hrast crniku (Quercus ilex L.) na Rabu Table 8. Results of regression analysis of flammability as dependent variable for holm oak (Quercus ilex L.) on the island of Rab

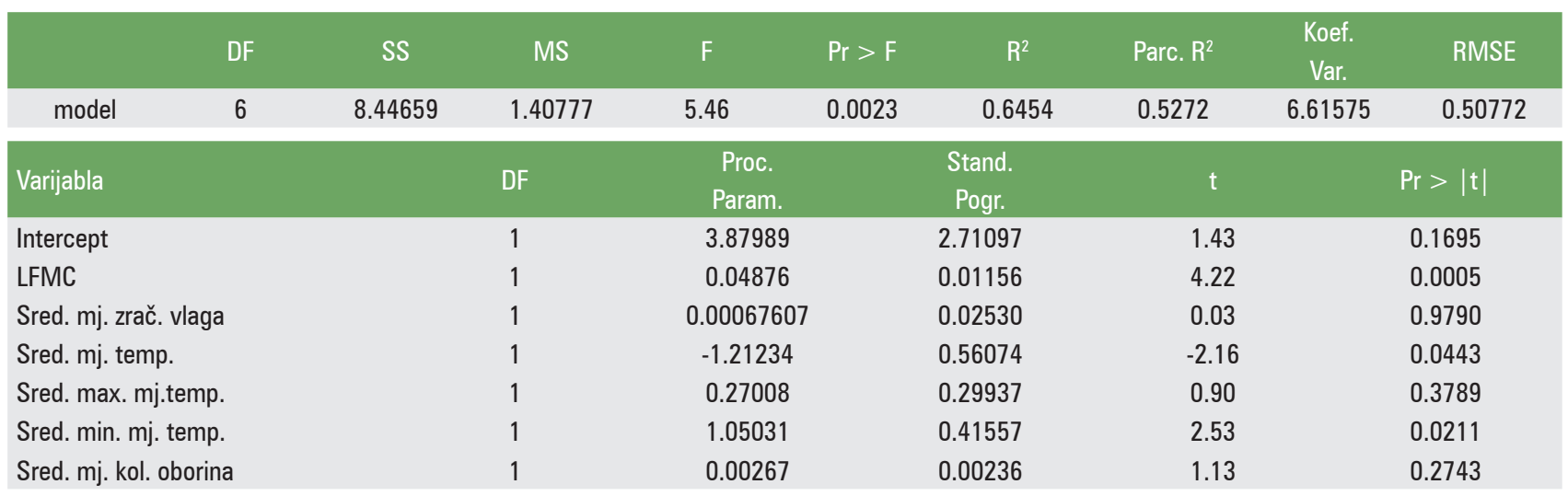

* LFMC - Live Fuel Moisture Content = sadržaj vlage živog goriva

Tablica 9. Rezultati stepwise procedure regresijske analize zapaljivosti kao zavisne varijable za hrast crniku (Quercus ilex L.) na Rabu Table 9. Results of stepwise procedure of regression analysis of flammability as dependent variables for holm oak (Quercus ilex L.) on the island of Rab

$\begin{array}{lcccccc}\text { Varijabla } & \text { Proc. } & \text { Stand. Pogr. } & \text { Tip II } & \text { P } & \text { Pr }>\text { F } & \text { Parc. } R^{2} \\ \text { Intercept } & \text { Param. } & & \text { SS } & & & \\ \text { LFMC } & 4.68546 & 1.08391 & 4.58440 & 18.69 & 0.0003 & 0.4136 \\ \text { Sred. mj. temp. } & 0.05257 & 0.00999 & 6.79475 & 16.22 & 0.0005 & 0.1372 \\ \text { Sred. min. mj. temp. } & -0.89400 & 0.33046 & 1.79560 & 7.32 & 0.0133 & 0.0555\end{array}$

Tablica 10. Rezultati regresijske analize gorivosti kao zavisne varijable za hrast crniku (Quercus ilex L.) na Rabu

Table 10. Results of regression analysis of fuel combustibility as dependent variables for holm oak (Quercus ilex L.) on the island of Rab

\begin{tabular}{|c|c|c|c|c|c|c|c|c|}
\hline DI & SS & MS & $\mathrm{F}$ & $\mathrm{Pr}>\mathrm{F}$ & $\mathrm{R}^{2}$ & Parc. $R^{2}$ & $\begin{array}{l}\text { Koef. } \\
\text { Var. }\end{array}$ & RMSE \\
\hline model & 4.40758 & 0.73460 & 0.69 & 0.6570 & 0.1880 & -0.0826 & 8.95588 & 1.02824 \\
\hline Varijabla & & DF & $\begin{array}{l}\text { Proc. } \\
\text { Param. }\end{array}$ & & $\begin{array}{l}\text { Stand. } \\
\text { Pogr. }\end{array}$ & $\mathrm{t}$ & & $\operatorname{Pr}>|t|$ \\
\hline Intercept & & 1 & 17.02350 & & 5.49030 & 3.10 & & 0.0062 \\
\hline LFMC & & 1 & -0.03538 & & 0.02342 & -1.51 & & 0.1482 \\
\hline Sred. mj. zrač. vlaga & & 1 & -0.03079 & & 0.05125 & -0.60 & & 0.5554 \\
\hline Sred. mj. temp. & & 1 & 0.40697 & & 1.13561 & 0.36 & & 0.7242 \\
\hline Sred. max. mj.temp. & & 1 & -0.37925 & & 0.60628 & -0.63 & & 0.5395 \\
\hline Sred. min. mj. temp. & & 1 & 0.01751 & & 0.84162 & 0.02 & & 0.9836 \\
\hline Sred. mj. kol. oborina & & 1 & 0.00374 & & 0.00479 & 0.78 & & 0.4453 \\
\hline
\end{tabular}

mjesečna količina oborina (tablica 8). Procedurom provedene regresijske analize utvrđeno je da najveći utjecaj ima sadržaja vlage goriva $\left(\mathrm{R}^{2}=0,41\right)$ i srednje mjesečne temperature $\left(\mathrm{R}^{2}=0,13\right)$ (tablica 9$)$.

Uzimajući u obzir iste varijable, rezultati regresijske analize gorivosti hrasta crnike na Rabu pokazuju da niti jedna od korištenih varijabli nema statistički značajan utjecaj na gorivost (tablica 10), što znači da sve korištene varijable podjednako utječu na gorivost hrasta crnike na Rabu (Rosavec, 2010).

\section{RASPRAVA I ZAKLJUČCI DISCUSSION AND CONCLUSIONS}

Područje Sredozemlja ili Mediterana jasno je određeno obalnom linijom Sredozemnog mora. Za šumsku vegetaciju posebno su važni klimatski uvjeti. Posebnosti mediteranske klime jasno se očituju u hodu temperature te povezanosti s količinom i rasporedom oborina tijekom godine. Općenito bitni meteorološki elementi o kojima ovisi cjelokupni biljni svijet su sunčevo zračenje, svjetlost, toplina, raspoložive količine vode tj. količina oborina i zaliha vode 
u tlu (Vučetić i Vučetić, 1995). U sredozemnom području često se kao posljedica određenih meteoroloških čimbenika javlja suša. Trajanje sušnog razdoblja uvjetuje i vegetaciju koja se može prilagoditi toj pojavi. Suša je dulje abnormalno pomanjkanje vlage, osim toga to je nedostatak ili potpuni izostanak oborina. $\mathrm{Na}$ intenzitet suše utječu temperatura zraka, brzina vjetra, relativna vlaga zraka i dr. Nadalje, uz sušu javlja se i evapotranspiracija koja utječe na zalihe vode u tlu. Naravno da se u navedenim stanišnim uvjetima zahtijeva prilagođenost šumske vegetacije, a to svojstvo adaptacije pokazuje i hrast crnika u različitim zajednicama na Sredozemlju. Premada je tolerantna vrsta na sušu i visoke temperature, manje je tolerantna od širokolisne zelenike (Phillyrea latifolia L.) i planike (Arbutus unedo L.) prema Peñuelas i dr. (2018).

Stanišni uvjeti u Sredozemlju iznimno su zahtjevni za obnovu šumske vegetacije (Španjol et al. 2006). Radi se o utjecaju podneblja i osnovnim značajkama zemljišnog pokrivača na kršu, gdje je izražena prostorna varijabilnost. Najvažniji čimbenici diferenciranja zemljišnog pokrivača na kršu jesu prema Vrbek et al. (1995): morfostruktura krškog terena, petrografske modifikacije supstrata, procesi okršavanja te antropogeni utjecaji. Na padinama uz kršku morfologiju zemljišni pokrivač je diferenciran denudacijskim procesima. Navedeno je tijekom stoljeća uz posebno izražen izravan ili neizravan čovjekov utjecaj djelovalo na smanjivanje površina crnikovih šuma te se negativno odrazilo u kvalitativnom smislu. Istovremeno mnogi autori danas (Terradas 1999, Roda i dr. 1999) smatraju da tipičan mediteranski tip vegetacije nije šuma, nego gusti vazdazeleni različiti oblici grmolike vegetacije kao što su makija i garig u Sredozemlju, „chaparral“ u Kaliforniji, „fynbos“ u Južnoafričkoj Republici, „matorral“ u Čileu i „mallee“ u Australiji.

Istovremeno, sa šumarskog gledišta, visoka šuma u ovom slučaju crnikove šume stabilniji su ekosustav i otporniji u smislu odnosa prema šumskim požarima (Dubravac i dr., 2018). Za razliku od niskih uzgojnih oblika iste šume koja se razlikuje po gustoći vrsta i većoj količini gorive tvari u prizemnom sloju i sloju grmlja. Sama gustoća makije osigurava brzinu širenja požara s velikom količinom šumskog gorivog materijala. U odnosu vegetacije i požara potrebno je poznavati odnos svake pojedine vrste prema zapaljivosti i gorivosti. Poznavanje obilježja šumskih goriva u pogledu zapaljivosti (sposobnost goriva da se zapali) i gorivosti (sposobnost goriva da održava vatru) vrlo je bitna u pogledu nastanka i širenja šumskih požara. Različite se metode koriste za utvrđivanje zapaljivosti i gorivosti. Najčešće primjenjivana jest ona koju je detaljno opisao Valette (1990), a koja se bazira na istraživanju zapaljivosti i gorivosti lisne mase. Dosadašnja istraživanja zapaljivosti i gorivosti označila su hrast crniku kao izrazito zapaljivu vrstu. Tako Dimitrakopoulos (2001) te Alessio i dr. (2008) svrstavaju hrast crniku u skupinu ekstremno zapaljivih vrsta. Nadalje, Alessio i dr.
(2008) pridodaju da je zapaljivost i gorivost slična tijekom cijele godine, odnosno zapaljivost i gorivost su gotovo podjednaki neovisno o tome da li se radi o mirovanju vegetacije ili vegetacijskoj aktivnosti. To potvrđuje i Rosavec (2010) koji je istražujući zapaljivost i gorivost hrasta crnike na Rabu utvrdio da se u promatranom razdoblju (lipanj 2007. - lipanj 2009.) zapaljivost kretala od 6,05 s do 9,27 sekundi, dok se gorivost kretala od 9,64 s do 13,94 sekundi. Rosavec (2010) je na temelju provedene regresijske analize utvrdio da statistički značajno na gorivost hrasta crnike utječu sadržaj vlage goriva te srednja mjesečna temperatura i srednja mjesečna količina oborina (tablica 10). U svakom slučaju bitna je razlika u strukturi šume crnike, jer šume visokog uzgojnog oblika i kvalitetnije panjače imaju manju zastupljenost i pokrovnost vrsta u prizemnom sloju, a sloja grmlja gotova da i nema. Stoga je eventualno širenje i razvoj požara usporeniji nego u makiji ili sastojini na prijelazu između makije i panjače. $U$ vegetacijskom smislu šume hrasta crnike na istraživanim plohama pod jakim su utjecajem interakcije biotskih čimbenika što se potvrđuje i u drugim sredozemnim zemljama (Lortie i dr. 2004) gdje ti čimbenici imaju jak utjecaj na strukturu i dinamiku biljnih zajednica. Na nekim istraživanim plohama (Rab-Kalifront) posebno je vidljiv negativan utjecaj prevelikog broja divljači po jedinici površine. U našem istraživanju (tablice 6 i 7) uočava se intenzitet tog negativnog utjecaja, posebice u sloju grmlja i prizemnog raslinja. Snimkama i praćenjem stanja u razdoblju od 2002., 2006., 2009. i 2014. godine zamjetan je izostanak diferenciranja vrsta u više slojeve. Stoga dolazi do stvaranja neravnoteže i narušavanja te promjena u progresivnoj sukcesiji (Callaway, 2007). Za obnovu u mediteranskom šumskom ekosustavu kritična je upravo faza ponika i pomlatka i njihov daljnji razvoj (Cuesta i dr. 2010).

U praćenju stanja na pokusnim plohama uočava se dinamika razvoja. Iz prvih izmjera trajne pokusne plohe (MAB ploha) br. 36 koje datiraju iz 1983. Godine, vidljivo je kako je tadašnja sastojina prema svom strukturnom obliku bila u prijelaznom stadiju između makije i panjače. Izmjerom 1993. godine utvrđeno je kako se sastojina razvija u smjeru progresivne sukcesije i polako se uzdiže prema kvalitetnoj panjači, jer dolazi do smanjivanja vrsta u sloju drveća i izdvajanja dominantnijih stabala (slika 3). To potvrđuju istraživanja Rauša i Matića (1987) i Rauša i dr. (1994) kojima je utvrđeno da se šuma na plohi br. 36 razvija iznimno dobro. Procesi sukcesije bez antropogenog utjecaja mogu se pratiti i na plohama na Brijunima (Tablice 2 i 3), Mljetu (Tablica 4) i Lokrumu (Tablica 5). Na navedenim plohama prisutni su procesi progresivne sukcesije, što je i očekivano, jer nije bilo destabilizirajućih čimbenika (npr. požari). Uvjeti za praćenje stanja i dinamiku razvoja su iznimno povoljni, jer se radi o zaštićenim područjima Nacionalnom parku i posebnom rezervatu šumske vegetacije. Trajne pokusne plohe osnovane su radi dugoročnih i kom- 
parativnih istraživanja šumskih ekosustava, a na njima će se vršiti i daljnja istraživanja koja će nastaviti prikazivati i objašnjavati procese sukcesije u klimatogenoj zajednici eumediterana. Preporuke za daljnja istraživanja odnosile bi se na interdisciplinarni pristup koji bi trebao obuhvatiti širi spektar istraživanja koja bi mogla adekvatnije odgovoriti na kompleksna pitanja upravljanja s mediteranskim šumskim ekosustavom; posebice procese sukcesije vegetacije s ciljem očuvanja i obnove sastojina hrasta crnike. Također, pitanja valorizacije šuma crnike s gledišta odnosa prema edafskoj eroziji, zatim smanjenju rizika od nastanka požara u odnosu na druge mediteranske vrste, očuvanja krajobraznih elemenata i niza drugih ekoloških uloga?

U eumediteranskoj vegetacijskoj zoni hrast crnika je temeljna šumska drvenasta vrsta. Iako je utvrđena značajna zapaljivost i gorivost hrasta crnike, rezultati se moraju promatrati u kontekstu razvoja sastojina i degradacijskih oblika. Gustoća i brojnost vrsta na određenoj površini je ključan čimbenik za povećani rizik od nastanka požara (makije i garizi). Za razliku od kvalitetnih panjača i šuma visokog uzgojnog oblika gdje se vlaga u tlu duže zadržava, vrlo mali broj vrsta nalazimo u sloju grmlja i prizemnog raslinja. Intenzivan antropogeni utjecaj smanjio je površine šuma hrasta crnike, stoga i u većim sačuvanim kompleksima na otoku Rabu (Kalifront) i na otoku Mljetu dominiraju sastojine niskog uzgojnog oblika (panjače). Na plohama koje se godinama istražuju utvrđeni su procesi sukcesije i razvoja sastojina.

\section{ZAHVALA}

\section{ACKNOWLEDGEMENT}

Na suradnji i iznimnoj pomoći na izmjeri pokusnih ploha, te obradi prikupljenih podataka studenticama i studentima Šumarskog fakulteta Sveučilišta u Zagrebu tijekom preddiplomskog i diplomskog studija. Rezultat njihovog rada su i diplomski radovi na Zavodu za ekologiju i uzgajanje šuma pod mentorstvom prof.dr.sc. Željka Španjola. Zahvala kolegici mag.ing.silv. Martini Kičić i kolegama mag.ing.silv. Ivanu Šafraniću i mag.ing.silv. Ivici Mikuleku.

\section{LITERATURA}

\section{REFERENCES}

- Alessio, G. A. Penuelas, J. Llusia, J. Ogaya, R. Estiarte, M. De Lillis, 2008: Influence of water and terpenens on flammability in some dominant Mediterranean species. Int. J. Wild. Fire 17, 274-286.

- Alexandrian, D., 1992: Forest trees: a technical French Mediterranean forest guide, Ed. 2, 92 str.

- Balen, J., 1935: Prilog poznavanju naših mediteranskih šuma. Šum. list 5: 177-190, Zagreb

- Barčić, D., Ž. Španjol, R. Rosavec, 2011: Značenje šuma u gospodarsko-ekološkoj i krajobraznoj valorizaciji otoka Raba. Rapski zbornik II, Ogranak Matice Hrvatske, 648 str., Rab.
- Baričević, D., I. Šapić, 2011: Prilog poznavanju sastava i raščlanjenosti šuma hrasta crnike u Istri. Croatian Journal of Forest Engineering, 32(1): 87-98.

- Baričević, D., I. Šapić, A. Leš, 2013: Fitocenološka analiza šuma hrasta crnike s crnim jasenom (Fraxino orni-Quercetum ilicis Horvatić /1956/1958) u Republici Hrvatskoj. U: Šumarstvo i poljoprivreda hrvatskog Sredozemlja na pragu Europske unije, zbornik radova, Anić, I., Tomić, F., Matić, S., (ur.), Zagreb, 1314.10. 2011., 3-15.

- Braun-Blanquet J. 1964: Pflanzensoziologie - Grundzüge der Vegetationskunde, Springer, Wien - New York.

- Callaway, R.M., 2007: Positive Interactions and Interference in Plant Communities. Spinger, Dordrecht, The Netherlands.

- Clausen, S. E., 1998: Applied Correspondence Analysis: An Introduction, Sage Publication Inc.

- Cuesta, B., P. Villar-Salvador, J., Puertolas, J.M. Rey Benayas, R. Michalet, 2010: Facilitation of Quercus ilex in mediterranean shrubland is explained by both direct and indirect interactions mediated by herbs. Journal of Ecology, 98, 687-696. doi: 10.1111/j.1365-2745.2010.01655.x

- Dimitrakopoulos, A.P., 2001: A statistical classification of Mediterranean species based on their flammability components. Int. J. Wild. Fire 10, 113-118.

- Dubravac, T., M. Turk, D. Barčić, 2018: Konverzija panjača hrasta crnike (Quercus ilex L.) oplodnim sječama-rezultati višegodišnjih znanstvenih istraživanja. Zbornik radova: Poljoprivreda i šumarstvo na kršu mediteransko-submediteranskog istočnojadranskog područja-stanje i perspektive. Posebna izdanja, Knjiga 27, (Ur), Šarić, T., Beus, V, Sarajevo, str: 103-121.

- Emberger, L., 1955: Une classification biogeographique des climats. Rec. Trav. Lab. Bot-Zool. Fac. Sci. Univ. Montpellier Bot 7:3-43. Eurostat. 2014. The EU in the world 2014. A statistical portrait. Statistical Books. Publications Office of the European Union,Luxembourg. $<$ http://ec.europa.eu/eurostat/documents/3217494/5786625/KSEX-14-001-EN.PDF> (pristupljeno 4/04/2016).

- Espelta, J.M., M. Riba, J. Retana, 1995: Patterns of seedling recruitment west-mediterranean Quercus ilex forests influenced by canopy development. Journal of Vegetation Science 6:465472.

- Flexas, J., A. Diaz-Espejo, J. Gago, A. Galle, J. Galmes, J. Gulias, H. Medrano, 2014: Photosynthetic limitations in Mediterranean plants: A review. Environmental and Experimental Botany 103: 12-23.

- Forestry Compendium 2000: CAB International (Global Module). Wallingford, Oxon.

- Horvat, A., 1965: Melioracije degradiranih šumskih terena, Šumarski fakultet,178 str., Zagreb

- Končar, S., 2017: Vegetacijsko-ekološka istraživanja na trajnim plohama Nacionalnog parka Brijuni, Diplomski rad, Šumarski fakultet Sveučilišta u Zagrebu.

- Krejči, V., T. Dubravac, 2004: Oplodnom sječom od panjače do sjemenjače hrasta crnike (Qurcus ilex L.) Šum. list 7-8: 405-412, Zagreb

- Lortie, C.J., R.W., Brooker, P., Choler, Z., Kikvidze, R., Michalet, F.I. Pugnaire, R.M., Callaway, 2004: Rethinking plant community theory. Oikos, 197, 433-438.

- Ljubić, I., 2014: Utjecaj proreda na pomlađivanje u panjačama hrasta crnike (Quercus ilex L.) na otoku Rabu. Diplomski rad, Šumarski fakultet Sveučilišta u Zagrebu. 
- Matić, S., Đ. Rauš, 1986: Prevođenje makija i panjača hrasta crnike u sastojine višeg uzgojnog oblika. Glasnik za šumske pokuse, posebno izdanje 2, 79-86, Zagreb.

- Moran-Lopez, T., A. Forner, D. Flores-Renteria, M. Diaz, F. Valladares, 2016: Some positive effects of the fragmentation of holm oak forests: attenuation of water stress and enhancement of acorn production. For Ecol and Manage 370: 22-30.

- Peñuelas, J., J. Sardans, I. Filella, M. Estiarte, J. Llusia, R. Ogaya, J. Carnicer, M. Bartrons, A. Rivas-Ubach, O. Grau, 2018: Assessment of the impacts of climate change on Mediterranean terrestrial ecosystems based on the data from field experiments and long-term monitored field gradients in Catalonia. Environmental and Experimental Botany 152:49-59.

- Prpić, B. 1986: Odnos hrasta crnike i nekih njegovih pratilica prema vodi i svjetlu. Glasnik za šumske pokuse 2: 69-75, Zagreb.

- Rauš, Đ., 1978: Šumski ekosistemi otoka Raba (od XVdo XX stoljeća). Šumarski list CII (1-3): 53-65, Zagreb.

- Rauš, Đ., 1986: Nastavno-pokusni šumski objekt Rab, Glasnik za šumske pokuse, posebno izdanje 2, 303.-321, Zagreb.

- Rauš, Đ., S. Matić, 1987: Gospodarenje i namjena rapskih šuma u prošlosti, sadašnjosti i budućnosti. Rapski zbornik, 99-110, Zagreb.

- Rauš, Đ., J. Vukelić, Ž. Španjol, T. Đuričić, 1994: Istraživanje sukcesije crnikovih šuma na trajnoj pokusnoj plohi (br. 36) na Rabu. Glasnik za šumske pokuse, 31, 93-134, Zagreb.

- Rodá, F., J. Retana, C.A. Gracia, J. Bellot, 1999: Ecology of Mediterranean Evergreen Oak Forests. Ecological Studies, Vol. 137, Springer-Verlag, Berlin Heidelberg, 373 str.

- Rimac, I., 2014: Razvoj šumske vegetacije na trajnim pokusnim plohama posebnog rezervata šumske vegetacije Lokrum. Diplomski rad, Šumarski fakultet Sveučilišta u Zagrebu.

- Rosavec, R., 2010: Odnos čimbenika klime i zapaljivosti nekih mediteranskih vrsta kod šumskih požara. Disertacija, Šumarski fakultet Sveučilišta u Zagrebu, 175 str.

- Sokal, R.R., F.J. Rohlf, 1995: Biometry. Freeman and Company. New York.

- Statsoft, Inc., 2007: Electronic Statistics Textbook (Electronic Version): Tulsa, OK: StatSoft. WEB: http://www.statsoft.com/ textbook/stathome.html.

- Šegulja, N., Đ. Rauš, 1993: Sto trajnih ploha Republike Hrvatske (ekološka istraživanja). Glas. šum. pokuse 29: 133-148, Zagreb.

- Španjol, Ž., 1995: Prirodna obilježja Raba. Barbat. Rab - Zagreb. 429 str.
- Španjol, Ž., D. Barčić, R. Rosavec, D. Ugarković, 2006: Ameliorative role of Aleppo pine (Pinus halepensis Mill.) in the regeneration of climatozonal vegetation. Periodicum Biologorum, Vol. 108, (6), 655.-662., Zagreb.

- Šumskogospodarska osnova područja Republike Hrvatske za razdoblje 2016. - 2025.

- Terradas, J., 1999: Holm Oak and Holm Oak Forests. In: Ecology of Mediterranean Evergreen Oak Forests. (Eds.) J. Bellot, Ecological Studies, Vol. 137, Springer-Verlag, Berlin Heidelberg, 3-13 str.

- Trinajstić, I., 1985: Fitogeografsko-sintaksonomski pregled vazdazelene šumske vegetacije razreda Quercetea ilicis Br.-Bl. u jadranskom primorju Jugoslavije. Poljopr. Šum. 31 (2-3): 71.96., Titograd.

- Trinajstić, I., 1986: Fitogeografsko raščlanjenje šumske vegetacije istočnojadranskog sredozemnog područja - polazna osnovica u organizaciji gospodarenja mediteranskim šumama. Glasnik za šumske pokuse, posebno izdanje 2, 53-67., Zagreb.

- Valladeres, F., R. Benavides, S.G. Rabasa, P.J.G. Paula, S.W.D. Simonson, M. Diaz, 2014: Global change and Mediterranean forest: current impacts and potential responses. In Comes D.A. and S.W. Burslem DFRP, ed. Forests and global change. Cambridge University Press, Cambridge.

- Valette, J.C., 1990: Inflammabilite des especes forestieres mediterraneennes. Consequences sur la combustibilite des formations forestieres, Rev. For. Fr. 42, 76-92.

- Vrbek, B., M. Benko, V. Krejči, 1995: Proizvodnost šumskih tala nacionalnog parka Mljet, U: P. Durbešić, A. Benović (ur.), Prirodne značajke i društvena valorizacija otoka Mljeta, Hrvatsko ekološko društvo, Državna uprava za zaštitu kulturne i prirodne baštine, Nacionalni park Mljet, 321.-328., Zagreb.

- Vučetić, M., V. Vučetić, 1995: Klimatske prilike otoka Mljeta kao čimbenik prilagodbe biljnog svijeta, U: P. Durbešić, A. Benović (ur.), Prirodne značajke i društvena valorizacija otoka Mljeta, Hrvatsko ekološko društvo, Državna uprava za zaštitu kulturne i prirodne baštine, Nacionalni park Mljet, 233.-243., Zagreb.

- Vukelić, J., 2012: Šumska vegetacija Hrvatske. Sveučilište u Zagrebu, Šumarski fakultet, Državni zavod za zaštitu prirode, Zagreb.

- Westhoff, V., E. van der Maarel, 1973: The Braun-Blanquet Approach. In: Whittaker R.H. (ur.) Ordination and Classification of Communities. The Hague, W. Junk, 617-726.

\section{SUMIMARY}

In the vegetative sense, holm oak forests are an integral part of the Mediterranean region, with holm oak appearing as the dominant tree species in the climatogenic community of the coniferous belt. The course of vegetation development, i.e. progression and regression, is seen in the succession of holm oak forests. Succession is present on the Croatian coast of the Adriatic Sea, and throughout the whole Mediterranean area. This paper provides an overview of the vegetation analyses and dynamics of development of holm oak forests. Research was conducted only on MAB plots and plots on Rab Island (Kalifront Peninsula, belonging to the Faculty of Forestry, University of Zagreb for the research of Rauš, Španjol and Barčić). Vegetation inventory generated a list of all plant species in the tree, shrub and undergrowth layers that were observed and recorded on the selected plots, with values for abundance (number) and cover. The combustibility and flammability of holm oak were analysed, since forest fires are the most significant threat to forest vegetation and vegetation in general in the Mediterranean zone. Multifactor analysis of variance (Sokal \& Rohlf, 1995) was applied to determine the 
flammability and combustibility for holm oak. Linear correlation analysis was applied to examine the relationship between individual variables. The course of vegetation development, i.e. progression and regression, shows the succession of holm oak forests (Figure 5). The figure indicates the long time period necessary for the succession of forest vegetation, particularly in the case of progressive succession and complete species conversion. This includes at least several rotations of pine stands, and is in direct correlation with the habitat conditions. The research of holm oak forests on the permanent experimental plots is particularly important. These plots are part of the international Man and Biosphere project $(\mathrm{MAB})$. Vegetation research in holm oak forests can be compared between the permanent experimental plots (PEPs) in the MAB project from the islands of Rab, Brijuni, Mljet and Lokrum (PEPs no. 36, 56 and 57, 37, 77, respectively). The succession processes on the PEPs are expressed through comparisons of time series monitoring data. They indicate the formation of stand structures and the emergence of the dominant tree layer (Figure 6). Understanding the properties of forest fuels in the sense of their combustibility (ability of fuel to combust) and flammability (ability of fuel to continue to burn) is very important for understanding the start and spread of forest fires. Different methods are used to determine combustibility and flammability. The most commonly used method is that described by Valette (1990), based on the research of combustibility and flammability of leaf litter. The regression analysis established that the moisture content of fuel, mean monthly air temperature, and mean monthly precipitation levels significantly affected the combustibility of holm oak (Table 10). However, the results of the regression analysis of the flammability of holm oak on Rab Island indicated that none of these variables had a statistically significant influence on flammability (Table 12). The PEPs were established for the purpose of long-term and comparative ecosystem research, and they will continue to be used for further research to explain the succession processes in the climatogenic Eu-mediterranean community.

KEY WORDS: eu-mediterranean, succession, growth dynamic, monitoring. 